\title{
Training bachelors in the transition to the use of domestic office software
}

\author{
Natalia Manyukova ${ }^{1}$,Elena Nikonova ${ }^{1, *}$, and Maksim Sliva ${ }^{1}$ \\ ${ }^{1}$ Nizhnevartovsk State University, 628605, 56 Lenina str., Nizhnevartovsk, Russia
}

\begin{abstract}
The article considers the requirements for the information competence of the students graduating with the bachelor degree in various areas of training. In particular, we analyze the software composition of the university and the possibility of its replacement with domestic or freely distributed programs.
\end{abstract}

The modern stage in the development of society has received the name of "information age," since its most important resource is information that determines the success of the development of science, economics, education, and other vital areas of activity. In this regard, there is a rapid development of information technology as a universal means of automating various information processes.

Information technologies play an important role in production and economics, since they significantly improve the efficiency of the business processes of the enterprise, and, consequently, its competitiveness.

In the management of any organization, information technology is used to implement a strictly defined process of collecting and processing information in order to make a managerial decision based on it. At the same time, the corporate information system, which takes into account all aspects of the company's activities, from planning and monitoring to analyzing economic information, will provide the maximum managerial effect.

An indispensable condition for the operation of such a system in an enterprise is the availability not only of the relevant software and work procedures, but also qualified personnel with the necessary competencies.

Therefore, the quality of training the future specialists in the field of Information Technology (ICT) is subject to special requirements.

Analysis of federal state educational standards of higher education [1] showed that practically for any direction of preparation, the requirements for the information culture of graduates are formulated, taking into account professional characteristics. An overview of such requirements in some areas of training being implemented at the Nizhnevartovsk State University is given in Table 1 .

\footnotetext{
*Corresponding author: niko_len@mail.ru
} 
Table 1. Content of ICT Competences of Bachelors in various areas of training.

\begin{tabular}{|c|c|}
\hline Directions of training & Content of ICT competence \\
\hline $\begin{array}{l}\text { 09.03.01 Informatics and Computer } \\
\text { facilities, } \\
\text { 01.03.02 Applied Mathematics and } \\
\text { Informatics, } \\
\text { 20.03.02 Environmental Management } \\
\text { and Water Use, } \\
\text { 38.03.02 Management, } \\
\text { 37.03.01 Psychology, } \\
\text { 45.03.01 Philology. }\end{array}$ & $\begin{array}{l}\text { Ability to solve standard tasks of professional activity } \\
\text { on the basis of information and bibliographic culture } \\
\text { with the use of information and communication } \\
\text { technologies, taking into account the basic information } \\
\text { security requirements. }\end{array}$ \\
\hline 44.03.01 Teacher Education & $\begin{array}{l}\text { The ability to use natural and mathematical knowledge } \\
\text { for orientation in the contemporary information space. }\end{array}$ \\
\hline $\begin{array}{l}\text { 09.03.02 Information Systems and } \\
\text { Technologies }\end{array}$ & $\begin{array}{l}\text { The ability to use modern computer technology to find } \\
\text { information in order to solve the task, to critically } \\
\text { analyze this information, and to justify the ideas and } \\
\text { approaches taken to solve it. }\end{array}$ \\
\hline 39.03.02 Social Work & $\begin{array}{l}\text { The ability to use basic methods, ways, and means of } \\
\text { obtaining, storing, processing information, skills of } \\
\text { working with a computer as a means of information } \\
\text { management, including in the Internet. }\end{array}$ \\
\hline $\begin{array}{l}\text { 54.03.02 Decorative and Applied Arts } \\
\text { and Crafts }\end{array}$ & $\begin{array}{l}\text { The ability to own a modern font culture and computer } \\
\text { technologies used in design. }\end{array}$ \\
\hline 21.03.01 Oil and Gas Business & $\begin{array}{l}\text { The ability to search, store, process, and analyze } \\
\text { information from various sources and databases, present } \\
\text { it in the required format using information, computer, } \\
\text { and network technologies; } \\
\text { The ability to understand the essence and importance of } \\
\text { information in the development of the modern } \\
\text { information society, to understand the dangers and } \\
\text { threats arising in this process, to comply with the basic } \\
\text { requirements of information security, including the } \\
\text { protection of state secrets; } \\
\text { The ability to own the basic methods and means of } \\
\text { obtaining, storing, processing information, working } \\
\text { with the computer as a means of information } \\
\text { management; }\end{array}$ \\
\hline $\begin{array}{l}\text { 46.03.02 Document Science and } \\
\text { Archival Studies }\end{array}$ & $\begin{array}{l}\text { The ability to use basic methods and means of } \\
\text { obtaining, storing, and processing information. }\end{array}$ \\
\hline
\end{tabular}

Thus, a graduating student with a Bachelor's degree in almost any field of training should possess modern methods of working with information, including methods of ensuring information security, be able to use modern information technologies in their professional activities, and be able to communicate with computer networks.

In addition to the above, employers want to receive a graduate, who is capable of adaptation, self-education, and self-development, which also requires a confident possession of modern information technology. Thus, the requirements of the professional community for the training of IT specialists were analyzed in the article by E. Z. Nikonova, [2].

Despite the different areas, types and tasks of future professional activity, the Nizhnevartovsk State University has a unified approach in the preparation of Bachelor's students in various areas of information technology [3, 4].

At the first stage, the student needs to master the most common tools of basic information technologies (word processors, graphic editors, spreadsheets, presentation preparation tools, database management systems, computer telecommunications facilities, 
multimedia technologies). At the same time, for each technology issues of information representation and its structuring, elements of the working environment and modes of operation, system of commands and user actions should be studied. When setting tasks and selecting methods for solving them using a specific technology, a contextual approach developed by A. A. Verbitsky is used, according to which the selection of the educational material takes into account the future professional activity of the student [5].

At the second stage, students use specialized software to solve professional problems. Depending on the direction of preparation, this may be:

- Information and reference systems, a special class of databases containing normative information, expert advice on various areas of activity (GarantPlus, Consultant);

- Corporate information systems (Standard Solutions - 1C: Enterprise, SAP);

- Mathematical packages (Mathcad, Maple);

- Geoinformation systems (Mapinfo Professional, ArcGIS);

- Instrumental programming environments (CodeGear, RAD Studio, FreePascal, MySQL, Python);

- Graphical editors and design systems (GIMP, InkScape, 3DsMax, AutoCAD, Blender, FreeCAD, CorelDRAW Graphics Suite x4);

- Publishing systems and text recognition programs (Adobe Page Maker, Abbyy FineReader, Sumatra PDF);

- Software for photo and web design (Adobe Web Premium);

- Translation software (OmegaT, Lingvo x3, Sanako Speak!, SDL, Study);

- Music editors (Sibelius for Education, WaveLab Elements 8EE).

As can be seen from the above review, almost all programs and packages used in universities and for educational and organizational purposes are produced abroad and are paid there. According to the Ministry of Mass Communications, the largest software vendors in Russia are Microsoft, SAP SE, and Oracle, which “... take in fact $80 \%$ of the Russian market, and their combined annual profit is 180 billion rubles, of which the share of the public sector is $75 \%$ " [6]. In order to reduce the cost of purchasing foreign programs, as well as supporting Russian software developers, the Ministry of Education and Science plans to transfer its subordinate institutions, including universities, to domestic office software (according to the Order of the Ministry of Education and Science of the Russian Federation N 1220 of December 14, 2017).

"The office software includes the operating system, communication software, office suite, mail applications, organizer, viewer, Internet browser, presentation editor, spreadsheet editor, text editor, file manager software, legal reference system, electronic system software workflow, and antivirus protection [7].

As operating systems, we offer certified domestic distributions, GosLinux and ALTLinux, which are multi-user, multitasking operating systems for 32-bit and 64-bit hardware platforms. According to the experience of implementing GosLinux in the work of the Federal Bailiff Service of Russia, it turned out to be 37 times cheaper than MS Windows licenses [8].

In the Nizhnevartovsk State University, within the framework of various disciplines, teachers attempted to introduce freely distributed software as an alternative to commercial foreign software. For example, E. Z. Nikonova [9] considered the possibilities of software tools for processing statistical information. About the software for teaching the course "Computer graphics and design" for students of various areas of training wrote E. A. Sliva [10], as well as about the problems of transition to free software in the study of geoinformatics [11]. M. V. Sliva also [12] tells about the use for the teaching of disciplines related to Robotics, the specialized software called "Fritzing," with an open source code for the design of electronic-mechanical devices. 
In addition to the operating system, Alta Education includes about 30 educational programs in addition to the operating system, but it is impossible to meet all the needs of the university for the preparation of Bachelor's students with their help, so one needs to replace the specialized software that cannot run under the Linux operating system.

In Table 2, in addition to the products of the ALT Education package, there are possible alternatives from the open source software category.

Table 2. Software used in the higher education system.

\begin{tabular}{|c|c|c|c|c|}
\hline \multirow{2}{*}{\multicolumn{2}{|c|}{ Type and purpose of the software }} & \multicolumn{2}{|c|}{ Platform } & \multirow{3}{*}{\begin{tabular}{|c}
$\begin{array}{c}\text { Components } \\
\text { of the } \\
\text { distribution, } \\
\text { Alt Edu. }\end{array}$ \\
$\square$
\end{tabular}} \\
\hline & & \multirow{2}{*}{$\begin{array}{l}\text { Windows } \\
\text { Microsoft } \\
\text { Windows }\end{array}$} & \multirow{2}{*}{$\begin{array}{c}\text { Linux } \\
\text { Alt Linux }\end{array}$} & \\
\hline OS & Operating system & & & \\
\hline \multirow{10}{*}{ Office } & $\begin{array}{l}\text { Office software } \\
\text { package }\end{array}$ & $\begin{array}{l}\text { Microsoft } \\
\text { Office }\end{array}$ & LibreOffice & \multirow{6}{*}{$\nabla$} \\
\hline & $\begin{array}{l}\text { The word } \\
\text { processor }\end{array}$ & Word & $\begin{array}{c}\text { LibreOffice } \\
\text { Writer }\end{array}$ & \\
\hline & Spreadsheets & Excel & $\begin{array}{c}\text { LibreOffice } \\
\text { Calc }\end{array}$ & \\
\hline & $\begin{array}{l}\text { Presentation } \\
\text { Wizard }\end{array}$ & PowerPoint & $\begin{array}{l}\text { LibreOffice } \\
\text { Impress }\end{array}$ & \\
\hline & Graphics editor & & $\begin{array}{c}\text { LibreOffice } \\
\text { Draw }\end{array}$ & \\
\hline & SUBD & Access & $\begin{array}{c}\text { LibreOffice } \\
\text { Base }\end{array}$ & \\
\hline & $\begin{array}{l}\text { Desktop } \\
\text { Publishing } \\
\text { System }\end{array}$ & Publisher & & \\
\hline & $\begin{array}{l}\text { Information } \\
\text { manager }\end{array}$ & Outlook & & \\
\hline & $\begin{array}{l}\text { Program for } \\
\text { creating quick } \\
\text { notes and } \\
\text { organizing } \\
\text { personal } \\
\text { information }\end{array}$ & OneNote & & \\
\hline & $\begin{array}{l}\text { Project } \\
\text { Management } \\
\text { Program }\end{array}$ & Project & OpenProj & \\
\hline File manager & & Conductor & Thunar & $\nabla$ \\
\hline \multirow{3}{*}{ Web } & \multirow[b]{2}{*}{ Web Browser } & Explorer & & \\
\hline & & $\begin{array}{l}\text { Mozilla } \\
\text { FireFox }\end{array}$ & Mozilla Firefox & $\nabla$ \\
\hline & $\begin{array}{l}\text { Client program } \\
\text { for instant } \\
\text { messaging }\end{array}$ & & Pidgin & $\nabla$ \\
\hline \multirow{4}{*}{ Service software } & Archive Manager & 7-Zip & Xarchiver & \\
\hline & & $\begin{array}{l}\text { Kaspersky } \\
\text { Anti-Virus }\end{array}$ & $\begin{array}{c}\text { Kaspersky Anti- } \\
\text { Virus } \\
\end{array}$ & \\
\hline & $\begin{array}{l}\text { Implementation } \\
\text { Windows API }\end{array}$ & & WINE & $\nabla$ \\
\hline & $\begin{array}{l}\text { Desktop } \\
\text { environment for } \\
\text { UNIX-like }\end{array}$ & & $\begin{array}{l}\text { XFCE } 4.12, \\
\text { KDE } 5.7\end{array}$ & $\square$ \\
\hline
\end{tabular}




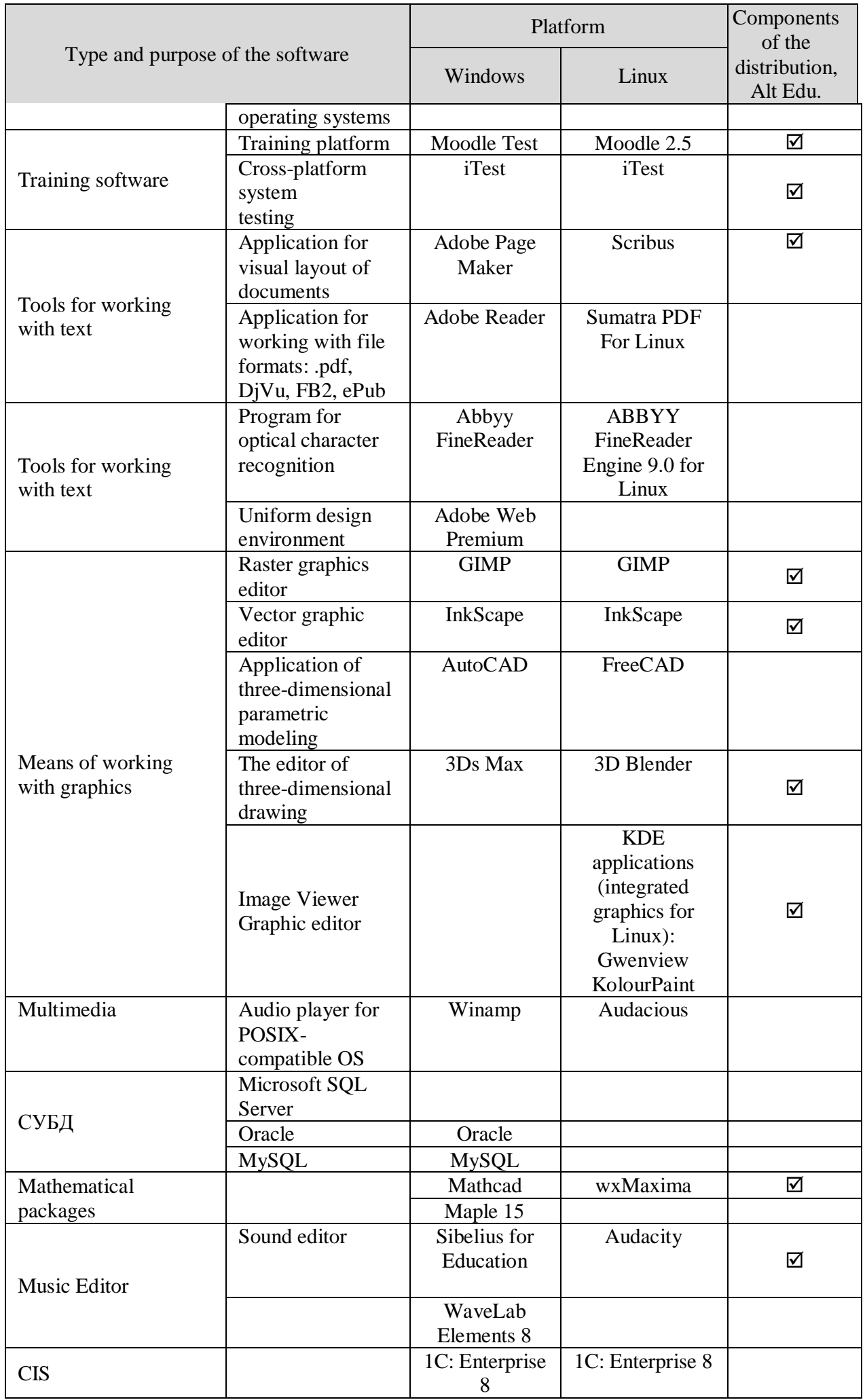




\begin{tabular}{|c|c|c|c|c|}
\hline \multirow{2}{*}{\multicolumn{2}{|c|}{ Type and purpose of the software }} & \multicolumn{2}{|c|}{ Platform } & \multirow{2}{*}{$\begin{array}{l}\text { Components } \\
\text { of the } \\
\text { distribution, } \\
\text { Alt Edu. } \\
\end{array}$} \\
\hline & & \multirow{2}{*}{$\begin{array}{c}\text { Windows } \\
\text { Mapinfo } \\
\text { Professional }\end{array}$} & \multirow[t]{2}{*}{ Linux } & \\
\hline \multirow{3}{*}{ GIS } & & & & \\
\hline & & ArcGIS & & \\
\hline & & QGIS & QGIS, NextGIS & \\
\hline \multirow{2}{*}{ Info-reference systems } & & Consultant & Consultant Plus & \\
\hline & & Garant Plus & & \\
\hline \multirow{12}{*}{$\begin{array}{l}\text { Programming and } \\
\text { tools }\end{array}$} & \multirow{6}{*}{$\begin{array}{l}\text { Programming } \\
\text { languages }\end{array}$} & TurboBasic & BASIC-256 & $\nabla$ \\
\hline & & & $\begin{array}{l}\text { Code::Blocks } \\
\text { free cross- } \\
\text { platform } \\
\text { development } \\
\text { environment } \\
\text { C/C++ }\end{array}$ & $\nabla$ \\
\hline & & FreePascal & Free Pasca & $\nabla$ \\
\hline & & Python 2.5 & Python 2.7 и 3.5 & \\
\hline & & PHP & PHP 5.6 & \\
\hline & & & Perl 5.22 & \\
\hline & $\begin{array}{l}\text { Application } \\
\text { Development } \\
\text { Environment }\end{array}$ & $\begin{array}{l}\text { CodeGear } \\
\text { RAD Studio }\end{array}$ & & \\
\hline & $\begin{array}{l}\text { Development } \\
\text { Environment } \\
\text { (Delphi, Pascal) }\end{array}$ & & Lazarus & $\nabla$ \\
\hline & $\begin{array}{l}\text { Development } \\
\text { environment for } \\
\text { microcontrollers }\end{array}$ & Arduino IDE & Arduino IDE & \\
\hline & $\begin{array}{l}\text { Free integrated } \\
\text { development } \\
\text { environment for } \\
\text { modular cross- } \\
\text { platform } \\
\text { applications }\end{array}$ & Eclipse & Eclipse & \\
\hline & $\begin{array}{l}\text { Integrated } \\
\text { software } \\
\text { development } \\
\text { environment }\end{array}$ & $\begin{array}{c}\text { MicroSoft } \\
\text { Visual Studio }\end{array}$ & & \\
\hline & $\begin{array}{l}\text { Platform for } \\
\text { developing web } \\
\text { applications }\end{array}$ & ASP.NET & & \\
\hline
\end{tabular}

At the same time, the federal government bodies should legally and financially support the domestic office software. In this regard, we can assume a greater demand for qualified specialists in the near future, such as developers, administrators, and specialists in the implementation of Russian software and its professional support.

But, nevertheless, a number of questions remain open: How to ensure the adaptation of graduates to working conditions at non-state enterprises in the region using commercial foreign software? Who will regulate the transition of private companies to Russian software? How fully will the functionality of Russian software products be able to replace the tools of commercial foreign professional programs?

\section{References}


1. Portal of Federal State Educational Standards of Higher Education (http://fgo svo.ru/, 2018)

2. E. Z. Nikonova, Education \& science-2016: proceedings of the international scientific and practical conference for science and education workers (Science and Innovation Center Publishing House, St. Louis, Missouri, 2016)

3. N. V. Manyukova, Culture, science, education: problems and prospects: IV allRussian scientific and practical conference (Nizhnevartovsk State University Publishing House, Nizhnevartovsk, 2015)

4. N. V. Manyukova, Problems and prospects for the development of regions and enterprises in the conditions of economic globalization: international scientific and practical conference (Ufa Institute (Branch) of the RUE, Ufa, 2015)

5. A. A. Verbitsky, Higher Education in Russia, 5 (2010)

6. Priority to the Russian software or good intentions the road to import substitution is paved (https://www.fcaudit.ru/blog/prioritet-rossiyskomu-softu/, 2015)

7. Laws, Codes, and Normative-Legal Acts of the Russian Federation (http://legalacts.ru/, n.d.)

8. How much is the Russian OS? The Declassified price GosLinux (http://www.cnews.ru/news/, n.d.)

9. E. Z. Nikonova, Traditions and innovations in the educational space of Russia, Khanty-Mansiysk Autonomous Okrug and the University of Nizhni Novgorod: proceedings of the $V$ all-Russian scientific and practical conference (Nizhnevartovsk State University, Nizhnevartovsk, 2016)

10. E. A. Sliva, Culture, science, education: problems and perspectives: proceedings of the III all-Russian scientific and practical conference (Nizhnevartovsk State University, Nizhnevartovsk, 2014)

11. E. A. Sliva, Traditions and innovations in the educational space of Russia, KhMAOUgra and the University of Nizhniy Novgorod: proceedings of the $V$ all-Russian scientific and practical conference (Nizhnevartovsk State University, Nizhnevartovsk, 2016)

12. M. V. Sliva, Traditions and innovations in the educational space of Russia, KhantyMansiysk Autonomous Okrug, NVNGU: materials of the VI regional scientific and practical conference (Nizhnevartovsk State University, Nizhnevartovsk, 2017) 